\title{
Heavy metals determination in honey samples using inductively coupled plasma-optical emission spectrometry
}

\author{
Hasan Mohammadi Aghamirlou', Monireh Khadem², Abdolrasoul Rahmani ${ }^{3}$, Marzieh Sadeghian ${ }^{4}$, Amir Hossein Mahvi ${ }^{1,5 *}$,
} Arash Akbarzadeh ${ }^{6}$ and Shahrokh Nazmara ${ }^{1}$

\begin{abstract}
Background: Honey contains a complex mixture of carbohydrates and other minor substances. Elements are minor constituents of honey that may threaten the human health in excess concentrations. So, determining the metals in honey helps its quality control as a food product. The aim of this study was to determine the concentrations of some metals in Iranian honey.

Methods: This study was performed in four regions of Ardabil, a province of Iran. Honey samples $(n=25)$ were digested in microwave oven by nitric acid and hydrogen peroxide, then analyzed using inductively coupled plasma- optic emission spectrophotometry (ICP-OES).

Results: No significant differences were observed in cadmium, zinc, nickel, and chromium levels between regions $(P>0.05)$. Zinc was the most abundant metal in honey samples $(1481.64 \mu \mathrm{g} / \mathrm{kg})$. Some metals had higher concentrations in the East region because of existence more industries there. The highest mean of lead level was $935.48 \mu \mathrm{g} / \mathrm{kg}$ in the East and the lowest was $205.4 \mu \mathrm{g} / \mathrm{kg}$ in the South region. The concentrations of metals were compared with recommended limits for foods. Some of them were higher than standard levels (lead) and some were lower than those (cadmium).
\end{abstract}

Conclusions: Metals are released into the environment through their use in industrial processes and enter the food chain from uptake by plants from contaminated soil or water. Metals concentration in various places depends on many variables, leading to their different concentrations in honey. Some control measures like the quality control of food products, monitoring the soil in agricultural regions and limiting the use of fertilizers are recommended.

Keywords: Honey, Inductively coupled plasma-optic emission spectrophotometry, Heavy metals

\section{Background}

Honey, produced by the honeybee, is a natural supersaturated sugar solution, which has been consumed as a high nutritive value food and is composed of a complex mixture of carbohydrates [1]. This natural product is so valuable as the only concentrated form of sugar available worldwide [2] and is also used as a food preservative. It also contains the certain minor constituents like enzymes

\footnotetext{
* Correspondence: ahmahvi@yahoo.com

'Department of Environmental Health Engineering, School of Public Health, Tehran University of Medical Sciences, Poursina St, Keshavarz Blvd, PO BOX: 6446-14155, Tehran, Iran

${ }^{5}$ Center for Solid Waste Research, Institute for Environmental Research,

Tehran University of Medical Sciences, Tehran, Iran

Full list of author information is available at the end of the article
}

(glucose oxidase, catalase, phosphatases), glucose and sucrose $(65-75 \%$ of total soluble solids), proteins, amino and organic acids, vitamins, lipids, volatile chemicals, flavonoids, phenolic acids, and minerals [3,4]. The biochemical properties of honey and its quality are related to honey maturity, climatic conditions, production methods, processing and storage conditions, as well as the nectar source of the honey [5-9].

Elements are minor constituents of honey. The kind of these elements in honey is related to the type of raw floral materials, i.e., the nectar, the pollen, and the honey dew, which are collected by bees [10-13]. Metal concentrations in different honey types depend largely on the elemental composition of flowers, with regard to their 
botanical and geographical origin [14,15]. These metals may come from external sources such as industrial smelter pollution, industrial unit emissions, and improper procedures during honey processing and maintenance stages. Also, the origin of metals in honey can be agrochemicals such as organic mercury, cadmium-containing fertilizers and arsenic-based pesticides (Figure 1) [14-16].

The presence of metals in honey may threaten the health of human as a consumer [17]. These metals can damage the quality of human life when they accumulate to a toxic concentration level [18]. In recent years, the concentrations of different metals in honey have been determined in some countries, such as China [17], Italy [14], France [19], Croatia [4], Slovenia [20], Poland [21], and Turkey [22-25]. Also, heavy metals in bees and in bee products have been the subject of many other various studies [26-32].

Heavy metals pollution is a serious problem in Iran because of the mining, smelting, and metal treatment industries. Heavy metals pollution affects the quality of productions, as well as the qualities of the atmosphere and waters, threatening the health and life of human beings and animals via the food chain. Although in Iran honey is produced and consumed on a large scale, there is a lack of information to determine the heavy metals in Iranian honeys [17]. In addition to its environmental importance, determining the heavy metals is important for the quality control of honey as one of the most complex food products. Therefore, the objective of the current study was to determine the concentrations of some heavy metals like copper $(\mathrm{Cu})$, zinc $(\mathrm{Zn})$, cadmium $(\mathrm{Cd})$, lead $(\mathrm{Pb})$, arsenic $(\mathrm{As})$, nickel $(\mathrm{Ni})$ and chromium $(\mathrm{Cr})$ in Iranian honey. The results of such studies can help prevent the mentioned problems and improve the healthy honey consumption. These results can lead to considering the

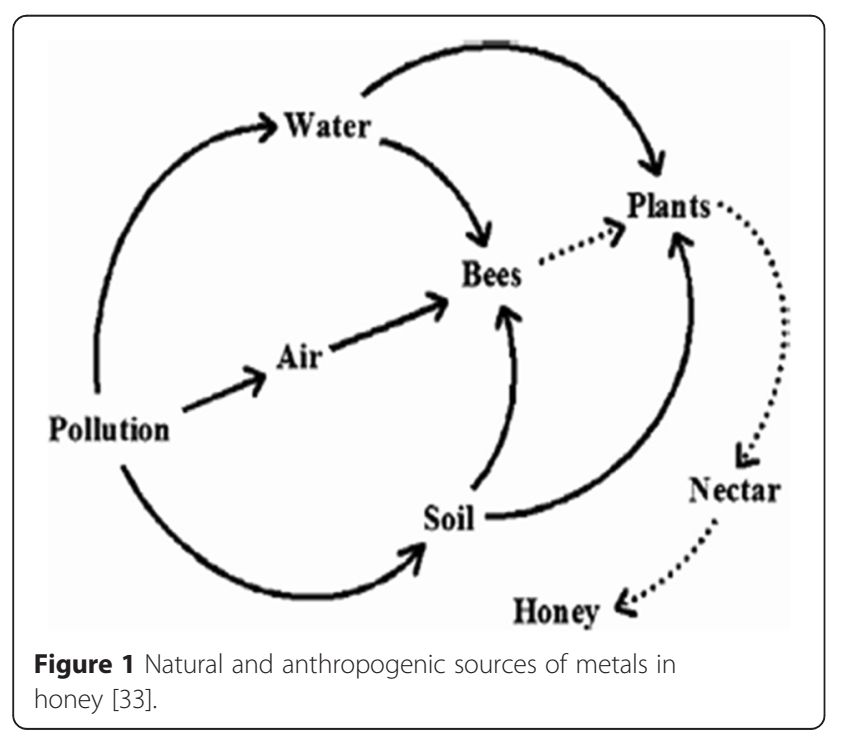

origins of honey contaminants such as soil type and air pollution, regarding the food safety in health policy, and providing best quality of food will protect public health and preserve consumer confidence.

\section{Methods}

\section{Sample collection}

This cross sectional study was performed in Ardabil, a province in North West of Iran, in 2013. During these year, a total of 25 samples of multi floral honey were collected from individual beekeepers in four regions of Ardabil: East (Ardabil County, $\mathrm{n}=6$ ), North (Moghan County, $n=7$ ), South (Khalkhal County, $n=6$ ) and West (Meshkinshar County, $\mathrm{n}=6$ ) (Figure 2). The Eastern region is the most populated, urbanized and industrialized in comparison with the other regions, particularly the South and North.

All honey samples ( $400 \mathrm{~g}$ ) were provided by the local association of bee keepers with guaranteed origin and made by traditional procedures in the honey-producing region; all samples were collected in clean and closed glass jars and immediately transferred to the laboratory of Department of Environmental Health at Tehran University of Medical Sciences; all samples were stored in glass bottles and kept at $4-8{ }^{\circ} \mathrm{C}$ in dark place until analysis.

\section{Apparatus}

Determination of Heavy metals was performed using an Octople Reaction System (ORS) inductively coupled plasma- optic emission spectrophotometry (ICP-OES), Spectro Arcos OES EOP (Germany).

Table 1 shows the ICP-OES operating conditions to do all metal analyses. A microwave oven (MARS 5, CEM) was used to digest the samples and their pretreatment. Instrumental parameters and settings for microwave digestion of samples were $15 \mathrm{~min} / 600 \mathrm{~W}$ at $120^{\circ} \mathrm{C}$, $20 \mathrm{~min} / 600 \mathrm{~W}$ at $180^{\circ} \mathrm{C}$ and venting for $20 \mathrm{~min}$.

\section{Reagents and chemicals}

All reagents were of analytical grade unless otherwise stated. Double-deionized water produced by Milli Q water purification system (Millipore) was used in all dilutions. The stock solutions of $\mathrm{Cu}, \mathrm{Cr}, \mathrm{Cd}, \mathrm{Pb}, \mathrm{As}, \mathrm{Ni}$ and $\mathrm{Zn}(1000 \mathrm{mg} / \mathrm{L}$, ICP standard CertiPUR) were purchased from Merck (Germany) and the elements standard solutions were prepared by diluting them. The same procedure was applied to prepare a solution of ${ }^{45} \mathrm{Sc},{ }^{89} \mathrm{Y},{ }^{159}$ $\mathrm{Tb}$ as an internal standard in the ICP-OES technique. Using the internal standard is recommended in routine analysis by ICP-OES to compensate the possible drift during long term runs and correct the matrix effects. Honey samples were digested by concentrated nitric acid (65\% $\mathrm{HNO}_{3}$ suprapure, Merck, Germany) and hydrogen peroxide $\left(30 \% \mathrm{H}_{2} \mathrm{O}_{2}\right.$ pure p.a, Chempur, Poland). 


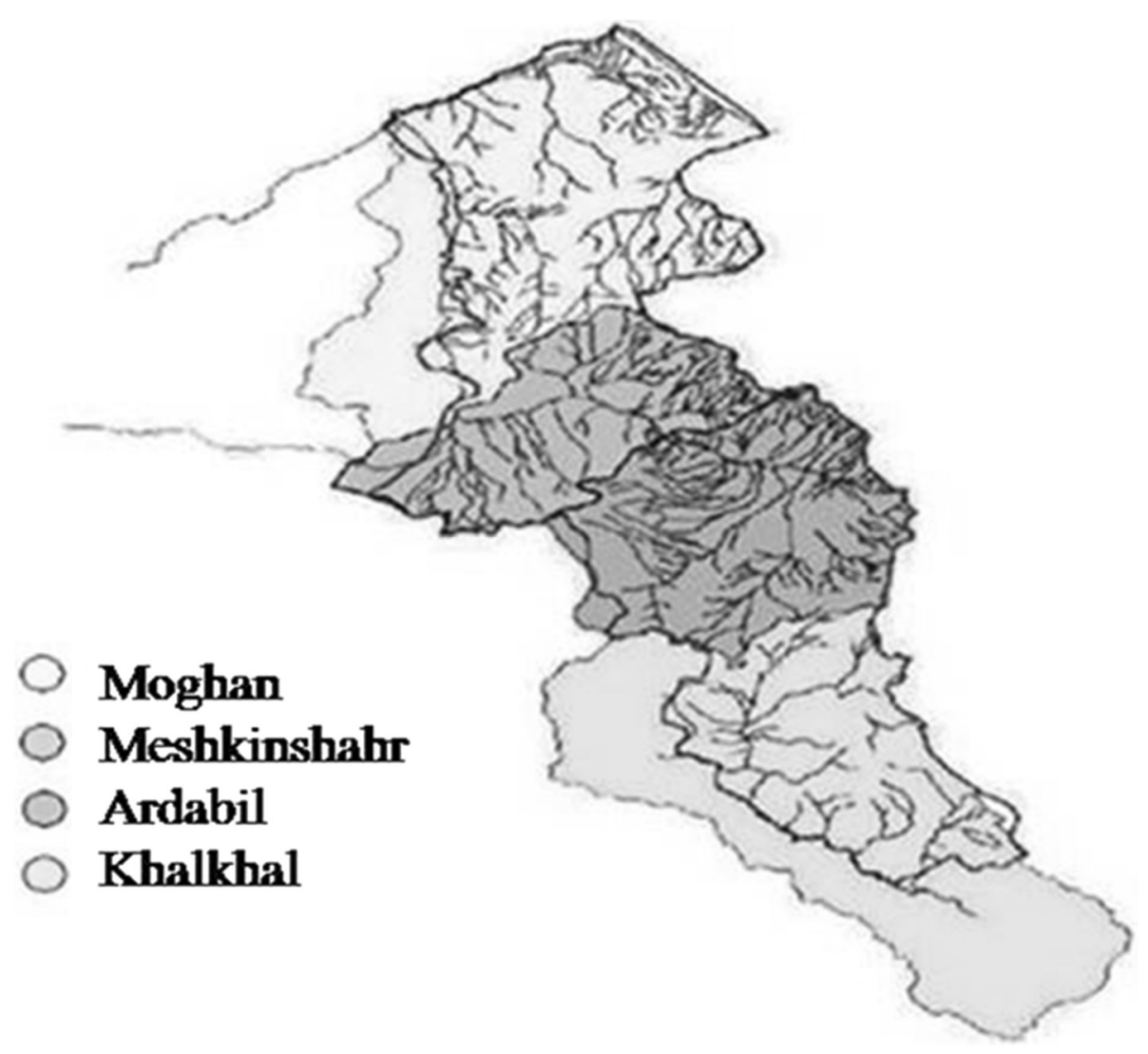

Figure 2 Geographical location of the four studied regions in the Ardabil province.

\section{Analytical procedures}

To determine seven mentioned metals, all honey samples were prepared according to the following procedure: exactly 1 gram of each sample was weighed in PTFE vessels and dissolved in 10 milliliter concentrated nitric acid $\left(\mathrm{HNO}_{3}\right)$. After that, samples were digested in the microwave oven [25]. This process was set in a closed system, so the sample decomposition had no contact with

Table 1 Instrumental characteristics and settings for ICP-OES

\begin{tabular}{ll}
\hline Spectrometer & Agilent 7500ce with ORS \\
\hline Nebulizer & Micromist \\
Interface & Interface \\
RF generator (W) & 1550 \\
Argon flow rate $\left(\mathbf{L ~} \mathbf{~ m i n}^{-1}\right)$ & 0.85 \\
Nebulizer pump (rps) & 0.10 \\
Scanning condition & Number of replicate 5, dwelling time 1 s \\
Scanning mode & Pulse \\
Reduction gas flow $\left(\mathbf{L ~ m i n}^{-1}\right):$ \\
H \\
He & 3.5 \\
Internal standard & 4.0 \\
\hline
\end{tabular}

external surroundings, thereby reducing the risk of contamination. Blank solutions were prepared by nitric acid.

ICP-OES technique is able to do the multi elemental analysis with excellent sensitivity and high sample throughout, resulting in high precision and accuracy. So it was used to determine the interested heavy metals in honey samples similar to other studies [14]. In some studies the analysis and measurements of heavy metals are done by atomic absorption and emission spectrometries [33].

The precision of the analytical method was evaluated in terms of repeatability of the experimental results of real samples and expressed as standard deviation (S.D). The accuracy was verified by calibration (using standard solutions). Additionally the internal standard $\left({ }^{45} \mathrm{Sc},{ }^{89} \mathrm{Y},{ }^{159} \mathrm{~Tb}\right)$ was applied for ICP-OES technique to correct the matrix effects.

\section{Data analysis}

The statistical calculations and analysis were performed using SPSS version 18 (SPSS Inc., Chicago, IL, USA). Some tests such as one-way ANOVA and T-test were used for data analyzing. The level of significance was taken as $\mathrm{p}<0.05$.

\section{Results}

To ensure the reliability of the results, the analysis of recovery rate was carried out by spiked honey samples for 
$\mathrm{Cu}, \mathrm{Cr}, \mathrm{Cd}, \mathrm{Pb}, \mathrm{As}, \mathrm{Ni}$ and $\mathrm{Zn}$. There was a good accuracy with recovery rates of $95-100 \%$ for metals (Table 2). As regards honey is mainly contains mineral trace elements, such as calcium, copper, iron, magnesium, manganese, potassium, and other minerals, in this study it was considered by applying the blank samples to obtain the accurate data. Blank honey samples are identified by the absence of compounds of interest (heavy metals), with prior injection into the detection system.

Table 3 indicates the concentration of metals in honey samples. The basic statistical data such as the number of samples, mean values, minimum and maximum values can be seen. Zinc is the most abundant metal in all honey samples having an average of $1481.64 \mu \mathrm{gkg}^{-1}$ (ranged from 122.86 to $6638.55 \mu \mathrm{gkg}^{-1}$ ). The other major metals, i.e. $\mathrm{Cu}, \mathrm{Cr}, \mathrm{Cd}, \mathrm{Pb}$ and $\mathrm{Ni}$ have the considerable lower averages in comparison with zinc. In the present study, the highest cadmium level was in the East region and the lowest was in the North. There were no significant differences between cadmium levels in various regions $(P=0.107)$. Also, no significant differences were observed in zinc, nickel, and chromium levels between regions $(\mathrm{P}>0.05)$.

Statistical analysis by ANOVA showed a significant difference between lead levels $(P=0.002)$ for honey samples in various regions. Furthermore, the highest mean of lead level was $935.48 \mu \mathrm{gkg}^{-1}$ in the East and the lowest was $205.4 \mathrm{\mu gkg}^{-1}$ in the South region. The highest and lowest levels of copper were seen in the West and North, respectively. No significant differences were observed in copper levels between regions $(\mathrm{P}=0.374)$.

\section{Discussion}

The aim of this study was to determine the concentrations of heavy metals in honey. It is worth to mention that there are no documented studies indicating the rate and pattern of metals in honey in Iran.

Based on our findings, the lowest and highest mean copper concentrations in the honey samples were in the North $\left(94.74 \mathrm{\mu gkg}^{-1}\right)$ and West $\left(591.49 \mu \mathrm{gkg}^{-1}\right)$, respectively. The mean of copper content in honey samples

Table 2 Heavy metals concentration and recoveries in spike honey samples

\begin{tabular}{llll}
\hline Element & $\begin{array}{l}\text { Certified value } \\
\left(\boldsymbol{\mu g ^ { - 1 } )}\right.\end{array}$ & $\begin{array}{l}\text { Measured value } \\
\left(\boldsymbol{\mu g g}^{-1}\right)\end{array}$ & Recovery (\%) \\
\hline As & 5.67 & $4.68 \pm 0.30$ & 95 \\
$\mathbf{C d}$ & 0.013 & $0.013 \pm 0.001$ & 100 \\
$\mathbf{C u}$ & 5.64 & $5.60 \pm 0.20$ & 99 \\
$\mathrm{~Pb}$ & 0.47 & $0.45 \pm 0.03$ & 97.2 \\
$\mathbf{Z n}$ & 12.5 & $10.9 \pm 0.9$ & 88.4 \\
$\mathbf{C r}$ & 0.3 & $0.29 \pm 0.03$ & 99 \\
$\mathrm{Ni}$ & 0.91 & $0.87 \pm 0.04$ & 96 \\
\hline
\end{tabular}

from all four regions was $243 \mu \mathrm{gkg}^{-1}$. The provisional tolerable daily intake (PTDI) for copper, set as a limit for metal intake based on body weight for an average adult (60 kg body weight) is $3 \mathrm{mg}$ [34]. Copper is a vital element to the health of all living things and in humans. However, too much ingestion of copper can lead to adverse health effects in the body. So, it is necessary to consider the daily intake of copper from different sources like food. In present study, the mean level of copper was much lower than those reported in previous surveys in, Italy $(647,310$ and $890 \mu \mathrm{gkg}-1)$ [14,35,36], Ireland $\left(0.2 \mathrm{mg} 100 \mathrm{~g}^{-1}\right)$ [37], and New Zealand (0.25 $\mathrm{mgkg}^{-1}$ ) [38], but higher than in other studies in the Black Sea Region of Turkey $\left(9.75-35.8 \mu^{-1 g^{-1}}\right.$ [23], china $\left(33.98 \mu \mathrm{gkg}^{-1}\right)$ [17] and New Zealand (163-182 $\mu \mathrm{gkg}^{-1}$ ) [39]. These are not completely consistent with our findings that may be due to differences in the studied regions like using different fertilizers or the diversity in practice of growing the plants.

Based on our findings, cadmium concentrations ranged from 1.36 to $125.88 \mu \mathrm{gkg}^{-1}$ with a mean value of $27.62 \mu \mathrm{gkg}^{-1}$ that was under the maximum permissible concentration $\left(200 \mu \mathrm{gkg}^{-1}\right)$ of cadmium [40]. Cadmium concentrations in this study were lower than those reported in Italy $\left(305 \mu \mathrm{gkg}^{-1}\right)$ [39], but higher than in other studies in china $\left(1.34 \mu \mathrm{gkg}^{-1}\right)$ [17], Turkey (0.9$\left.17.9 \mu \mathrm{gkg}^{-1}\right)$ [24], Macedonia $\left(3.63 \mu \mathrm{gkg}^{-1}\right)$ [41], Poland $\left(0.015 \mathrm{mgkg}^{-1}\right)$ [21], Italy $\left(3.91 \mu \mathrm{gkg}^{-1}\right)$ [14], Romania $\left(0.015 \mu \mathrm{gkg}^{-1}\right)$ [42], Turkish $\left(0.32 \mu \mathrm{gkg}^{-1}\right)$ [43] and Turkey $\left(0.38-2.03 \mu \mathrm{gkg}^{-1}\right.$ [23]. This is not completely consistent with our findings may be due to differences in the studied regions in various surveys. Cadmium is released into the environment through its use in various industrial processes, and enters the food chain from uptake by plants from contaminated soil or water. Therefore, the cadmium concentration in various places depends on many variables, leading to its different concentration in honey samples in those places.

Based on our findings, the lowest and the highest mean of lead concentrations were $205.4 \mu^{-1 k^{-1}}$ in the honey sample from the South and $935.48 \mu \mathrm{gkg}^{-1}$ in the East. The mean of lead content in honey samples from all four regions was $507.58 \mu \mathrm{gkg}^{-1}$ that last two concentrations exceed the standard level of $300 \mu \mathrm{gkg}^{-1}$, recommended by FAO/WHO/1984 [40]. Lead can be found in many products and locations. Lead gets into the air and then mixes with the soil near one of its sources, entering into the plants. So, lead concentration in some food like honey can be elevated depending on a lot of variables. In this study, lead concentration in honey samples from the East is higher than other regions. Therefore the soil contamination with lead may be occurred in the East, causing its uptake into the plants feeding bees. Also, lead has no beneficial role in human metabolism and can 
Table 3 Concentrations of heavy metals in different types of honey $\left(\mu \mathrm{gkg}^{-1}\right)$

\begin{tabular}{|c|c|c|c|c|c|c|c|c|c|}
\hline \multirow[t]{2}{*}{ Region } & \multirow[t]{2}{*}{$\mathbf{N}$} & \multicolumn{8}{|c|}{ Analyzed Metals $\left(\mu \mathrm{gkg}^{-1}\right)$} \\
\hline & & Statistics & As & $\mathrm{Cd}$ & $\mathrm{Cr}$ & $\mathrm{Pb}$ & $\mathrm{Ni}$ & $\mathrm{Zn}$ & $\mathrm{Cu}$ \\
\hline \multirow[t]{4}{*}{ North } & 7 & mean & $<11.87$ & 17.58 & 820.74 & 324.75 & 608.17 & 775.74 & 94.74 \\
\hline & & Minimum & $<11.87$ & 1.36 & 172.37 & 144.95 & 65.04 & 122.86 & 27.65 \\
\hline & & Maximum & $<11.87$ & 82.74 & 1220.3 & 960.88 & 1094.49 & 2265.38 & 150.12 \\
\hline & & SD & & 28.99 & 316.24 & 285.02 & 301.38 & 746.78 & 49.1 \\
\hline \multirow[t]{4}{*}{ South } & 6 & mean & $<11.87$ & 12.84 & 887.52 & 205.4 & 630.07 & 2725.09 & 97.96 \\
\hline & & Minimum & $<11.87$ & 7.49 & 850.39 & 117.46 & 585.07 & 433.84 & 71.43 \\
\hline & & Maximum & $<11.87$ & 19.12 & 932.38 & 380.17 & 677.77 & 5491.75 & 143.71 \\
\hline & & SD & & 4.96 & 33.92 & 93.3 & 34.61 & 1888.51 & 25.84 \\
\hline \multirow[t]{4}{*}{ East } & 6 & mean & $<11.87$ & 53.64 & 947.24 & 935.48 & 707.24 & 1043.47 & 212.53 \\
\hline & & Minimum & $<11.87$ & 11.48 & 895.71 & 431.64 & 622.68 & 240.45 & 96.75 \\
\hline & & Maximum & $<11.87$ & 125.88 & 1020.67 & 1627.82 & 805.66 & 2031.42 & 631.79 \\
\hline & & SD & & 47.97 & 52.92 & 473.51 & 77.82 & 753.56 & 211.34 \\
\hline \multirow[t]{4}{*}{ West } & 6 & mean & $<11.87$ & 28.08 & 956.64 & 595.16 & 593.92 & 1499.92 & 591.49 \\
\hline & & Minimum & $<11.87$ & 9.16 & 711.58 & 134.28 & 450.96 & 169.30 & 85.48 \\
\hline & & Maximum & $<11.87$ & 64.92 & 1165.68 & 871.24 & 879.38 & 6638.55 & 2872.74 \\
\hline & & SD & & 19.14 & 151.95 & 246.1 & 143.6 & 2543.95 & 1118.22 \\
\hline \multirow[t]{4}{*}{ All samples } & 25 & mean & $<11.87$ & 27.62 & 899.75 & 507.58 & 651.78 & 1481.64 & 243 \\
\hline & & Minimum & $<11.87$ & 1.36 & 172.37 & 117.46 & 65.04 & 122.86 & 27.65 \\
\hline & & Maximum & $<11.87$ & 125.88 & 1220.3 & 1627.82 & 1094.49 & 6638.55 & 2872.74 \\
\hline & & SD & & 32 & 184.03 & 402.14 & 173.29 & 1709.81 & 559.3 \\
\hline
\end{tabular}

cause some health disorders. Thus, it must be considered seriously.

Antonescu and Mateescu [44] reported that no samples of Rumanian honey contained $\mathrm{Cd}$ and As, while it contained lead of $0.1-200 \mathrm{\mu gkg}^{-1}$ in the range within the limits imposed by the last regulations of the Codex Alimentarius [45]. The measured lead concentration was almost higher than those found in honey samples from china $\left(33.98 \mu \mathrm{gkg}^{-1}\right)$ [17], Croatia $\left(65.2 \mu \mathrm{gkg}^{-1}\right)$ [4], New Zealand $\left(0.017 \mathrm{mgkg}^{-1}\right)$ [38], Turkey $\left(17.6-32.1 \mu \mathrm{gkg}^{-1}\right)$ [25], Poland $\left(0.048 \mathrm{mgkg}^{-1}\right)$ [21], Romania $\left(0.07 \mu \mathrm{gkg}^{-1}\right)$ [42] and in samples from Taiwan and mainland China (0.007-0.029 $\mathrm{mgkg}^{-1}$ ) [46]. However, the lead concentrations found in this study were lower than those found in honeys from Italian areas $\left(2370 \mu \mathrm{gkg}^{-1}\right)$ [47], Slovenia (5.94 $\left.\mathrm{mgkg}^{-1}\right)$ [20] and Italy $\left(620 \mu \mathrm{gkg}^{-1}\right)$ [39].

The mean arsenic concentration in all honey samples was $<11.87 \mu \mathrm{gkg}^{-1}$, which was below the maximum allowable level $\left(10-500 \mu \mathrm{gkg}^{-1}\right)$, regulations of the Codex Alimentarius [45] and Commission Regulation [48]. In comparison with the very few measured contents in the literature, the arsenic levels obtained were higher than levels found in Siena County, Italy (6.59 and $<0.5 \mu \mathrm{gkg}^{-1}$ ) $[14,35]$. However, the arsenic concentrations were lower than those found in honeys from Croatia $\left(19.7 \mu \mathrm{gkg}^{-1}\right)$ [4], Slovenia (1.24-1.49 $\mathrm{mgkg}^{-1}$ ) [20], and New Zealand $\left(0.08 \mathrm{mgkg}^{-1}\right)$ [38]. Environmental pollution factors that may contribute to the presence of arsenic in honey may be caused by non-ferrous metallurgy, factories, and agrochemicals such as fertilizers, and arsenic-based pesticides. Arsenic is also found in food, water, soil, and air. It is absorbed by all plants, therefore can present in honey. Some control measures such as the quality control of food products and limiting the use of arsenic-based pesticides are recommended.

Zinc can be toxic at high concentrations and plants affected may show symptoms similar to those found in other heavy metal toxicities [49]. In most cases, excess $\mathrm{Zn}$ generates reactive oxygen species and/or displaces other metals from active sites in proteins [50]. Zinc is an essential mineral required by the body for keeping a healthy immune system, building proteins and other processes. The most important sources of anthropogenic zinc in soil come from discharges of smelter slags and wastes, mine tailings and the use of commercial products such as fertilizers and wood preservatives that contain zinc. The average recommended as daily intake in foods is estimated to be $12-15 \mathrm{mg} /$ day for zinc [51-53]. In the present study, the maximum and minimum $\mathrm{Zn}$ concentrations were $6638.55 \mu^{-1 k^{-1}}$ in the West and $122.86 \mu \mathrm{gkg}^{-1}$ the North. The results showed that $\mathrm{Zn}$ was the most abundant metal in honeys with an average 
value of $1481.64 \mu \mathrm{gkg}^{-1}$. This average $\mathrm{Zn}$ concentration was lower than those found in honey samples from Siena County of Italy $(1820 \mu \mathrm{gkg}-1)$ [14], Italy (3205 $\mu \mathrm{gkg}-1$ ) [39], and Slovenia (3.61 mgkg-1) [20]. However, the obtained $\mathrm{Zn}$ levels were higher than levels found in china (1329.5 $\mu \mathrm{gkg}-1)$ [17], New Zealand (1.18 mgkg-1) [37], Taiwan and mainland China (0.996 mgkg-1) [54]. Keeping honey in galvanized containers might be the source of $\mathrm{Zn}$ contamination in honeys [55]. Some researchers have expressed that diverse metal concentrations in honeys is extremely reliant on the kind of flowers utilized by bees and it can be the chief source of $\mathrm{Zn}$ contamination [15]. Although zinc is an essential element for human body, high intake of it may be led to adverse health effects. Thus, the quality control of food products is necessary.

Based on our findings, the mean of nickel content in honey samples from all four regions were $651.78 \mu \mathrm{gkg}^{-1}$. The mean of nickel in the East region is more than other ones that may be related to more industrial sources of nickel there. The intake of nickel via food is related to several factors such as the source of nickel and distance from the contamination source. Nickel is present in the air, water, and soil and is generally distributed uniformly through the soil profile. The level of $5 \mathrm{mg} / \mathrm{kg}$ body weight/day was determined for nickel by joint FAO/WHO Expert Committee on Food Additives (JEFCA). Our findings were not similar with the previous reports in which nickel concentration was not detected $[43,56,57]$.

Chromium (Cr) is listed by the Environmental Protection Agency as one of the 129 priority pollutants and one of the 14 most noxious heavy metals [58]. The general population is exposed most often by ingestion through chromium content in soil, food, and water [59]. Trivalent chromium is the most common natural state of chromium and an essential nutrient. Its Recommended Daily Intake is 30 to $100 \mu \mathrm{g} /$ day for adults. However, the primary route of non occupational exposure to chromium is food ingestion. Chromium in foodstuffs is considered to be in the trivalent form [60]. Based on our findings, chromium concentrations ranged from 172.37 to $1220.3 \mu \mathrm{gkg}-1$ with a mean value of $899.75 \mu \mathrm{gkg}-1$. The highest mean chromium concentrations were $1220.3 \mu \mathrm{gkg}-1$ in the honey samples from the North region. According to the Expert Group on Vitamins and Minerals (EVM) a total daily intake of about $0.15 \mathrm{mg}$ chromium (III) $/ \mathrm{kg}$ bw/day (or $10 \mathrm{mg} /$ person/day) would be expected to be without adverse health effects, whereas the WHO considered that supplementation of chromium should not exceed $250 \mu \mathrm{g} /$ day (European Food Safety Authority 2010) [61]. According these regulations and data, chromium concentrations in studied honey samples can be considered in an acceptable range. Because of the lack of studies in this field, it is not possible the comparison of present study with other investigations. Finally, the mean concentrations of each heavy metal were compared between four regions. There were significant differences $(\mathrm{P}<0.05)$ between regions for all heavy metals excepting arsenic.

Many people would like to drink their tea with honey. Since, black tea has heavy metals, the overall heavy metal intakes should be considered $[62,63]$.

\section{Conclusion}

The present study indicated all types of honey contain metals and the metals concentrations vary among different regions because of some variables. Findings showed that zinc and arsenic had the maximum and minimum concentrations, respectively. Some geological and geochemical parameters may affect the honey chemistry. The proximity to the industries, having different types of soil, using various fertilizers, and the diversity in practice of growing the plants may be led to some differences between regions. However, further studies of the honeys are required, especially respecting the comparison of metals concentration with standard level based on body weight and honey consumption. In this study, it was difficult to compare the obtained results with related standards, because some standards were based on daily or weekly intake of metals, while there was no data about daily consumption of honey by peoples. Finally, according to literatures, some recommendations can be mentioned, such as limiting the consumption of hazardous fertilizers, monitoring the soil in agricultural regions, considering the distance of agricultural lands and flower gardens with industries, controlling the quality of food products, providing some accurate standards limits for hazardous compounds in the foods, and monitoring the waters that is used for agriculture and flower working. Since, due to the corrosive effect of honey, its contact with stainless steel surfaces and galvanized containers can be a source of chromium and zinc, using proper containers for storage of the honey is recommended.

\section{Competing interests}

The authors declare that they have no competing interests.

\section{Authors' contributions}

Conception and design, Data Collection, Analysis and interpretation: HMA MS, AR, SN. Writing the manuscript, Critical revision of the manuscript: AHM, MK, AR. Statistical Expertise, final approval of the manuscript: AHM, MK. All authors read and approved the final manuscript.

\section{Acknowledgements}

This is a part of research. The authors would like to thank the financial support of Deputy of Research, Tehran University of Medical Sciences, and members of the laboratory for supporting this research.

\section{Author details}

'Department of Environmental Health Engineering, School of Public Health, Tehran University of Medical Sciences, Poursina St, Keshavarz Blvd, PO BOX: 6446-14155, Tehran, Iran. ²Department of Occupational Health Engineering, School of Public Health, Tehran University of Medical Sciences, Tehran, Iran. ${ }^{3}$ Department of Occupational HealthEngineering, School of Health and Nutrition, Shiraz University ofMedical Sciences, Shiraz, Iran. ${ }^{4}$ Department of 
Occupational Health Engineering, School of Public Health, International Campus, Shahid Beheshti University of Medical Sciences, Tehran, Iran. ${ }^{5}$ Center for Solid Waste Research, Institute for Environmental Research, Tehran University of Medical Sciences, Tehran, Iran. ${ }^{6}$ Department of Epidemiology and Biostatistics, School of Public Health, Tehran University of Medical Sciences, Tehran, Iran.

\section{Received: 24 April 2014 Accepted: 12 April 2015} Published online: 01 May 2015

\section{References}

1. Saxena S, Gautam S, Sharma A. Physical, biochemical and antioxidant properties of some Indian honeys. Food Chem. 2010;118:391-7.

2. Krell R. Value-Added Products from Beekeeping, FAO Agricultural Services Bulletin No. 124. Rome, Italy: Food and Agriculture Organization of the United Nations; 1996.

3. Blasa M, Candiracci M, Accorsi A, Piacentini MP, Albertini MC, Piatti E. Raw Millefiori honey is packed full of antioxidants. Food Chem. 2006;97:217-22.

4. Bilandzic N, Dokic M, Sedak M, Kolanovic BS, Varenina I, Koncurat A, et al. Determination of trace elements in Croatian floral honey originating from different regions. Food Chem. 2011;128:1160-4.

5. Guler A, Bakan A, Nisbet C, Yavuz O. Determination of important biochemical properties of honey to discriminate pure and adulterated honey with sucrose (Saccharumofficinarum L.) syrup. Food Chem. 2007;105:1119-25.

6. Bogdanov $\mathrm{S}$, Harmonised methods of the international honey commmission: IHC responsible for the methods Swiss Bee Research Centre, FAM, 1999, Liebefeld, Switzerland, Available online: http://www.usamvcluj.ro/Diagnoza/ HCmethods_e.pdf.

7. Crane E. Honey: a comprehensive survey. London: Heinemann, International Bee Research Association (IBRA); 1979.

8. Oddo LP, Bogdanov S. Determination of honey botanical origin: problems and issues. Apidologie. 2004:35:S2-3.

9. White Jr JW. Honey. In: Chichester CO, Mrak EM, Stewart GF, editors. Advances in Food Research. New York: Academic Press; 1978. p. 288-374.

10. Baroni MV, Arrua C, Nores ML, Faye P, Diaz MDP, Chiabrando GA. Composition of honey from Cordoba (Argentina): assessment of North/ South provenance by chemometrics. Food Chem. 2009;114:727-33.

11. Nanda V, Singh B, Kukreja VK, Bawa AS. Characterization of honey produced from different fruit plants of northern India. Int J Food Sci Technol. 2009;44:2629-36.

12. Juszczak L, Socha R, Roznowski J, Fortuna T, Nalepka K. Physicochemical properties and quality parameters of herb honeys. Food Chem. 2009;113:538-42.

13. Silva LR, Videira R, Monteiro AP, Valentao P, Andrade PB. Honey from Luso region (Portugal): physicochemical characteristics and mineral contents. Microchem J. 2009;93:73-7.

14. Pisani A, Protano G, Riccobono F. Minor and trace elements in different honey types produced in Siena county (Italy). Food Chem. 2008;107:1553-60.

15. Rashed MN, Soltan ME. Major and trace elements in different types of Egyptian mono-floral and non-floral bee honeys. J Food Compos Anal. 2004;17:725-35.

16. Wang J, Kliks MM, Jun S, Li QX. Residues of organochlorine pesticides in honeys from different geographic regions. Food Res Int. 2010;43:2329-34.

17. Ru QM, Feng Q, He JZ. Risk assessment of heavy metals in honey consumed in Zhejiang province, southeastern China. Food Chem Toxicol. 2013:53:256-62.

18. Munoz Olivas R, Camara C. Speciation related to human health. In: Ebdon L, Pitts L, Cornelis R, Crew H, Donard OFX, Quevauviller P, editors. Trace element speciation for environment, food and health. UK: The Royal Society of Chemistry; 2001. p. 331-53.

19. Devillers J, Dore JC, Marenco M, Poirier-Duchene F, Galand N, Viel C. Chemometrical analysis of 18 metallic and nonmetallic elements found in honeys sold in France. J Agric Food Chem. 2002;50:5998-6007.

20. Golob T, Dobersek U, Kump P, Necemer M. Determination of trace and minor elements in Slovenian honey by total reflection $\mathrm{X}$-ray fluorescence spectroscopy. Food Chem. 2005;91:593-600.

21. Przybylowski P, Wilczynska A. Honey as an environmental marker. Food Chem. 2001:74:289-91.

22. Citak D, Silici S, Tuzen M, Soylak M. Determination of toxic and essential elements in sunflower honey from Thrace region, Turkey. Int J Food Sci Technol. 2012;47:107-13.
23. Silici S, Uluozlu OD, Tuzen M, Soylak M. Assessment of trace element levels in Rhododendron honeys of Black Sea Region, Turkey. J Hazardous Mater. 2008;156:612-8.

24. Tuzen M, Silici S, Mendil D, Soylak M. Trace element levels in honeys from different regions of Turkey. Food Chemist. 2007;103:325-30.

25. Tuzen M, Soylak M. Trace heavy metal levels in microwave digested honey samples from middle Anatolia, Turkey. J Food Drug Anal. 2005;13:343-7.

26. Bromenshenk JJ, Carlson SR, Simpson JC, Thomas JM. Pollution monitoring of Puget sound with honey bees. Science. 1985;227:632-4.

27. Conti ME, Botre F. Honeybees and their products as potential bio-indicators of heavy metal contamination. Environ Monit Assess. 2001;69:267-82.

28. Fakhimzadeh K, Lodenius M. Heavy metals in Finnish honey, pollen and honey bees. Apiacta. 2000;35:85-95

29. Kalnins MA, Detroy BF. The effect of wood preservative treatment of beehives on honey bees and hive products. J Agric Food Chemist. 1984;32:1176-80.

30. Leita L, Muhlbachova G, Cesco S, Barbattini R, Mondini C. Investigation of the use of honey bees and honey bee products to assess heavy metals contamination. Environ Monitor Assess. 1996:43:1-9.

31. Roman $A$. The influence of environment on accumulation of toxic elements in honey bees' body. ISAH. 2005;2:423-6.

32. Veleminsky M, Laznicka P, Stary P. Honeybees (Apismellifera) as environmental monitors of heavy metals in Czechoslovakia. Acta Entomol Bohemoslov. 1990;87:37-44.

33. Pohl P. Determination of metal content in honey by atomic absorption and emission spectrometries. TrAC Trends Anal Chem. 2009;28:117-28.

34. Joint FAO/WHO. Expert committee on food additives. Rome, Italy: Summary and conclusions, 53rd meeting 1-10; 1999.

35. Caroli S, Forte G, lamiceli AL, Galoppi B. Determination of essential and potentially toxic trace elements in honey by inductively coupled plasma based techniques. Talanta. 1999;50:327-36.

36. Conti ME. Lazio region (central Italy) honeys: a survey of mineral content and typical quality parameters. Food Control. 2000;11:459-63.

37. Downey G, Hussey K, Kelly JD, Walshe TF, Martin PG. Preliminary contribution to the characterization of artisanal honey produced on the island of Ireland by palynological and physico-chemical data. Food Chem. 2005;91:347-54.

38. Vanhanen LP, Emmertz A, Savage GP. Mineral analysis of mono-floral New Zealand honey. Food Chem. 2011;128:236-40.

39. Buldini PL, Cavalli S, Mevoli A, Sharma JL. Ion chromatographic and voltametric determination of heavy and transition metals in honey. Food Chem. 2001;73:487-95

40. Al-Eed MA, Assubaie FN, El-Garawany MM, El-Hamshary H, El-Tayeb ZM. Determination of heavy metal levels in common spices. Egypt J Appl Sci. 2002;17:87-98

41. Stankovska E, Stafilov T, Sajn R. The content of cadmium in honey from the republic of Macedonia. Ekoloskazastitazivotnesredine. 2006;10:11-7.

42. Bratu I, Beorgescu C. Chemical contamination of bee honey identifying sensor of the environment pollution. J Cent Eur Agric. 2005;6:95-8.

43. Erbilir $F$, Erdogrul $O$. Determination of heavy metals in honey in Kahramanmaras city, Turkey. Environ Monit Assess. 2005;109:181-7.

44. Antonescu C, Mateescu C. Environmental pollution and its effects on honey quality. Romanian Biotechnol Letter. 2001;6:371-9.

45. 45. Codex Alimentarius: Standard for Hone. Ref Nr. CL 1993/14, SH FAO/ WHO, Rome; 1993.

46. Wang $Y H, X u D M$, Hung $C H$, Cheng SR, Yu JY, Lee MS, et al. Investigation of PCDD/FS, dioxin-like PCBs and metal element in honey from Taiwan and Mainland China. Adv Mat Res. 2011;356:908-13.

47. D'Ambrosio M, Marchesini A. Heavy metal contamination of honey. Atti Societa Italiana Scienze Naturali. 1982;123:342-8.

48. The Commission of the European Communities. Setting maximum levels for certain contaminations in foodstuffs, Commission Regulation (EC) No 1881/ 2006, Official Journal of the European Union; 2006: L364/9.

49. Foy CD, Chaney RL, White MC. The physiology of metal toxicity in plants. Annu Rev Plant Physiol. 1978;29:511-66.

50. Marschner H. Mineral nutrition of higher plants. London: Academic; 1995

51. Agency for Toxic Substances and Disease Registry (ATSDR). Toxicological profile for Zinc. Atlanta, GA: U.S. Department of Health and Human Services, Public Health Service; 2005. p. 5-10.

52. World Health Organization (WHO). Toxicological evaluation of certain food additives. Geneva: Joint FAO/WHO expert committee of food additives. WHO Food Additives Series, number 17; 1982. 
53. National Research Council. Dietary reference intakes for vitamin a, vitamin k, arsenic, boron, chromium, copper, iodine, iron, manganese, molybdenum, nickel, silicon, vanadium, and zinc. Washington, D.C: National Academy Press; 2000.

54. Standardization Administration China, Ministry of Health, China (SAC/MOHC). Maximum levels of contaminants in foods. Beijing: SAC/MOHC; 2005.

55. Gonzalez Paramas AM, Gomez JA, Garcia Villanova RJ, Rivas Pala T, ArdanuyAlbajar R, Sanchez S, et al. Geographical discrimination of honeys by using mineral composition and common chemical quality parameters. J Sci Food Agric. 2000;80(1):157-65.

56. Yilmaz H, Yavuz O. Content of some trace metals in honey from south-eastern Anatolia. Food Chem. 1999;65(4):475-6.

57. Latorre MJ, Pena R, Pita C, Botana A, Garcia S, Herrero C. Chemometric classification of honeys according to their type II: metal content data. Food Chem. 1999;66(2):263-8.

58. Sharma P, Bihari V, Agarwal SK, Verma V, Kesavachandran CN, Pangtey BS, et al. Groundwater contaminated with hexavalent chromium [Cr ( VI)]: a health survey and clinical examination of community inhabitants (Kanpur, India). PLoS One. 2012;7(10):e47877.

59. U.S. Department of Health and Human Services: Chromium Toxicity. Public Health Service, Agency for Toxic Substances and Disease Registry (ATSDR),Publication No: ATSDR-HE-CS-2001-0005; 2000.

60. Department for Environment, Food and Rural Affairs and the Environment Agency: Contaminants in Soil: Collation of Toxicological Data and Intake Values for Humans; Chromium. Environment Agency, Rio House, Water side Drive, Aztec West, Almondsbury, BRISTOL, BS324UD; 2002. Available online: http://www.enviroreporter.com/files/32002_UK_Chromium_standards.pdf.

61. EFSA Panel on Food Additives and Nutrient Sources added to Food: Scientific Opinion on the safety of trivalent chromium as a nutrient added for nutritional purposes to foodstuffs for particular nutritional uses and foods intended for the general population (including food supplements). EFSA Journal. 2010, 8 (12), doi:10.2903/j.efsa.2010.1882. http://www.efsa.europa.eu/en/efsajournal/ pub/1882.htm.

62. Moghaddam MA, Mahvi A, Asgari A, Yonesian M. Determination of aluminum and zinc in Iranian consumed tea. Environ Monit Assess. 2008;144(1-3):23-30.

63. Shekoohiyan S, Ghoochani M, Mohagheghian A, Mahvi AH, Yunesian M, Nazmara S. Determination of lead, cadmium and arsenic in infusion tea cultivated in north of Iran. Iranian J Environ Health Sci Eng. 2012;9(1):1-6.

\section{Submit your next manuscript to BioMed Central and take full advantage of:}

- Convenient online submission

- Thorough peer review

- No space constraints or color figure charges

- Immediate publication on acceptance

- Inclusion in PubMed, CAS, Scopus and Google Scholar

- Research which is freely available for redistribution 